\title{
ORIGINAL
}

\section{Glycolipid Enzyme Models. X. Catalysis of Glycolipids with Amino Acid Residue}

\author{
Yasukazu OHKAtsu, Miho OzAwa, Yoshiko NumatA, \\ and Nobuhiro NAKAMURA \\ Department of Applied Chemistry, Faculty of Engineering, Kogakuin University, \\ (1-24-2 Nishishinjuku, Shinjuku-ku, Tokyo, $\mathbf{T} 163$ )
}

\begin{abstract}
Glycolipids classified into two categories were synthesized and applied, as hydrolase models, to the hydrolyses of $p$-nitro-anilides of amino acids ; one had a sugar group at the end (hydrophilic part) of a glycolipid molecule and the other had a histidine group bonded to $\omega$-position of the sugar moiety. Both types of glycolipids could recognize the kinds of amino acids like $\alpha$-chymotrypsin, but the combination system of both categories of glycolipids only recognized them in different modes. The combination system, however, distinguished the D, L-configuration of amino acids better than other glycolipids. In particular, it distinguished D, $\mathrm{L}^{-}$alanines perfectly like an enzyme. The recognition mechanism is discussed.
\end{abstract}

Key words : Hydrolase model, Complete D,L-stereorecognition, Alanine ester, Glycolipid, $\alpha$-Chymotrypsin

\section{Introduction}

Enzymes are substrates that catalyze bio-reactions, and are characterized by such speci-

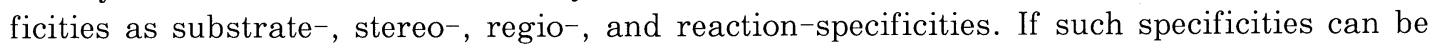
easily realized in organic chemical reactions, it will be highly useful. Recently, many chemists have developed and proposed enzyme models, although the realization of such specificities is only one of the reasons why they conduct model researches. Most of the models have been designed to act like enzymes in the stereochemistry of substrates and products, regardless of the kinds of reactions.

Enzymatic processes consist of the formation of a complex by taking-in of a substrate and the production of a product by decomposition of the complex as explained by MichaelisMenten mechanism as follows :

$$
\begin{aligned}
& |E|+|S| \underset{k_{-1}}{\stackrel{k_{1}}{\rightleftharpoons}}|E \cdot S| \stackrel{k_{\text {cat }}}{\longrightarrow}|E|+|P| \\
& k_{2}
\end{aligned}
$$

In general, an enzyme includes a hydrophobic pocket to take up a hydrophobic substrate. Enzyme model systems on the basis of concept mentioned above are often constructed by utilizing micelle and vesicle-forming, "amphiphilic", substance(s), which can provide a reaction field mimicking a hydrophobic pocket.

$\alpha$-Chymotrypsin, a hydrolase, whose structure and mechanism of action have been clarified relatively well, can hydrolyze peptide chains at the C-terminals of amino acids with an increased hydrophobicity, such as phenylalanine and thirosine. It hydrolyses ester substrates, too. Many researches of hydrolase models have been devoted to D, L-recognition of

Corresponding author : Yasukazu OHKATSU 
substrates, especially D and L-phenylalanine esters. Almost all researches use alkylated amino acids, especially, histidine derivatives with a higher alkyl chain, as model catalysts, in the presence of amphiphilic substance(s). The D, - -recognition ability of such models is 80 at the highest. A model system consisting of special components, however, gives an enzyme-like recognition. For example ${ }^{1), 2)}$, a model system using a peptide catalyst

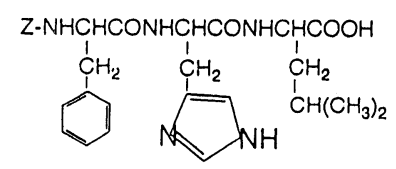

in the mixed vesicular system of

$$
\mathrm{CH}_{3}\left(\mathrm{CH}_{2}\right)_{14} i^{\mathrm{N}}\left(\mathrm{CH}_{3}\right)_{2} \mathrm{Br}^{-} \text {and } \mathrm{CH}_{3}\left(\mathrm{CH}_{2}\right)_{15} \stackrel{+}{N}\left(\mathrm{CH}_{3}\right)_{3} \mathrm{Br}
$$

has been reported, in terms of the hydrolysis of a phenylalanine ester.

Simple glycolipids were also reported to hydrolyze esters ${ }^{3), 4)}$ as well as amides ${ }^{5)}$ of amino acids, without any other amphiphiles, because the glycolipids can form micelles and vesicles

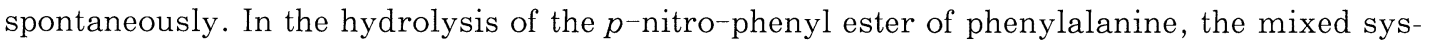
tem consisting of

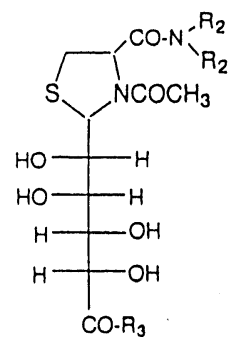

and
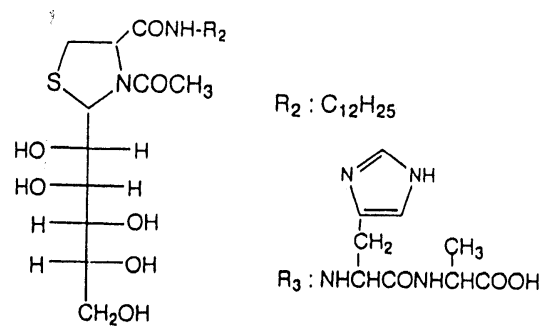

gave a considerably high D, L-recognition ability $(102)^{4)}$. Further, it has also been reported that glycolipids can distinguish the kinds of amino acids ${ }^{3}$.

In this paper, the recognition abilities for the $\mathrm{D}, \mathrm{L}-$ configuration and kinds of amino acids by glycolipid modified with histidine are examined and compared with those of a glycolipid without such an amino acid moiety. In addition, the complete recognition of $\mathrm{D}, \mathrm{L}$-alanine anilides is reported.

\section{Experimental}

\section{$2 \cdot 1$ Reagents}

\section{$2 \cdot 1 \cdot 1$ Substrates}

$p$-Nitro-anilides of $N$-benzyloxycarbonyl-phenylalanine, -leucine, -valine, -methionine, -alanine, and -glycine were used as substrates. They were synthesized as described elsewhere $^{6)}$.

\section{$2 \cdot 1 \cdot 2$ Glycolipids}

Glycolipids derived from hexoses such as glucose, galactose, mannose, L-rhamnose, and $\mathrm{L}-$ fucose, and pentoses such as xylose, ribose, and arabinose were also synthesized as described in previous papers ${ }^{5), 6)}$. They are represented, noting the presence or absence of a thiazolidine ring derived from cystein. The case of mannose (Man) is shown below as an example : 

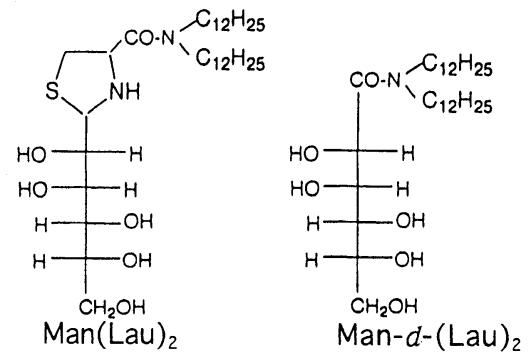

In this study, the following glycolipids were also used as a model catalyst modified with histidine $\left[\mathrm{Man}(\mathrm{Lau})_{2}\right.$-HisCOOMe, called Glycolipid (A)], and as a reaction field (Man Lau).
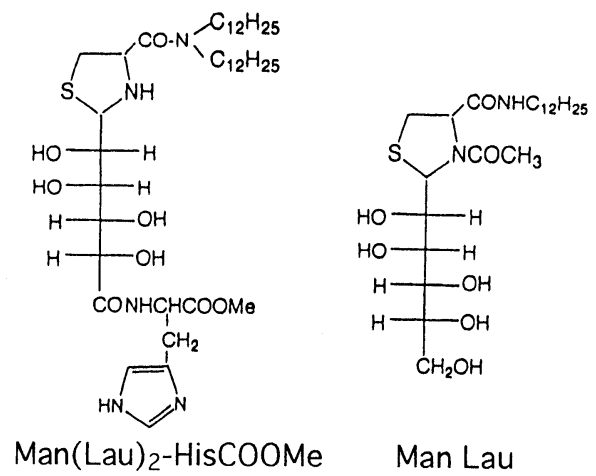

The Man(Lau $)_{2}-$ HisCOOMe was synthesized according to Scheme 1. First Man(Lau $)_{2}$ was synthesized by the trytyl method ${ }^{6}$. Then $\operatorname{Man}(\mathrm{Lau})_{2}\left(7 \times 10^{-3} \mathrm{~mol}, 4.33 \mathrm{~g}\right)$ was dissolved in a small amount of methylene chloride, to which $2 \mathrm{~mL}$ of $61 \%$ nitric acid was added, and the mixture was stirred at $0^{\circ} \mathrm{C}$ for $6 \mathrm{~h}$. The methylene chloride phase was extracted with neutralizing, followed by dehydration, and then was evaporated. The residue was dissolved in ethyl acetate, washed completely with water, dried, and then evaporated. Petroleum ether was added to the residue, and the resulting mixture was cooled to remove decomposed Man $(\mathrm{Lau})_{2}$ by filtration. The product $\mathrm{Man}(\mathrm{Lau})_{2}-\mathrm{COOH}$ was obtained from the filtrate.

Yield : 10.1\%.

IR $\left(\mathrm{cm}^{-1}\right)$ : 3300, 1090, $1050(-\mathrm{OH}), 2920,2850,1460\left(-\mathrm{CH}_{3},-\mathrm{CH}_{2}-\right), 1640(-\mathrm{CON})$.

The $\mathrm{Man}(\mathrm{Lau})_{2}-\mathrm{COOH}(0.42 \mathrm{~g})$ was dissolved in $N, N$-dimethyl formamide, to which the di-hydrogen chloride salt of L-histidine methyl ester $(0.091 \mathrm{~g})$, prepared previously, and triethyl amine $\left(1.08 \times 10^{-3} \mathrm{~mol}\right)$ were added. The mixture was stirred at $0^{\circ} \mathrm{C}$ for $3 \mathrm{~h}$ and, then, at room temperature for $24 \mathrm{~h}$. After removal of unreacted materials, the residue was dis-

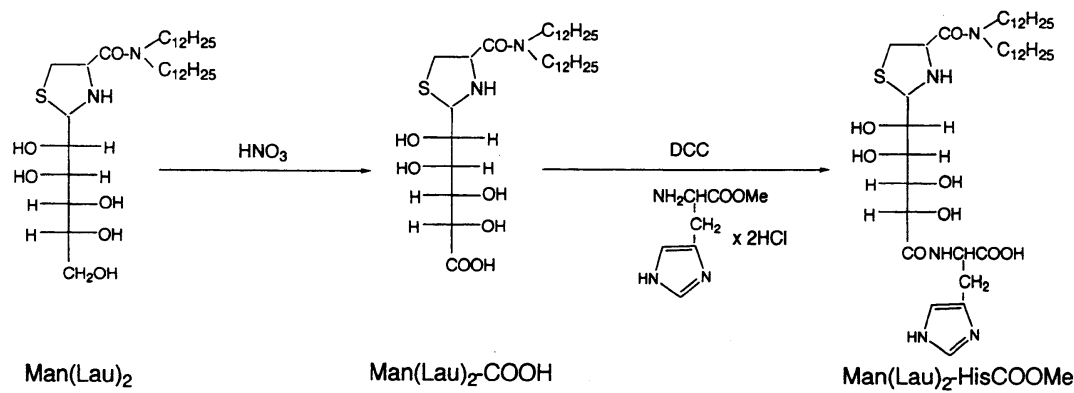

Scheme 1 Synthesis of Man(Lau $)_{2}-\mathrm{HisCOOMe.}$ 
solved in methylene chloride, and washed with $10 \%$ citric acid, $4 \%$ sodium hydrogen carbonate, and saturated $\mathrm{NaCl}$ solution, successively. The product was recovered after purification through a silica gel column (eluent : chloroform : methanol, $17: 3$ ).

Yield : $10.0 \%$.

IR $\left(\mathrm{cm}^{-1}\right): 3300(-\mathrm{OH}), 2920,2850,1460\left(-\mathrm{CH}_{3},-\mathrm{CH}_{2}-\right), 1710(-\mathrm{CONH}-), 1630\left(-\mathrm{C}=\mathrm{N}^{-}\right)$

${ }^{1} \mathrm{H}-\mathrm{NMR}\left(\mathrm{CDCl}_{3}\right)(\mathrm{ppm}): 8.3(1 \mathrm{H}, \mathrm{N}=\mathrm{CH}-\mathrm{N}), 7.5(1 \mathrm{H}, \mathrm{C}=\mathrm{CH}-\mathrm{N}), 4.5-3.5(6 \mathrm{H},-\mathrm{OH}), 1.6$ $\left(46 \mathrm{H},-\mathrm{CH}_{2}-\right), 1.2\left(9 \mathrm{H},-\mathrm{CH}_{3}\right)$

\subsection{Procedure}

Hydrolyses of $p$-nitro-anilides with glycolipid(s) were carried out by the method described in a paper ${ }^{6)}$. In the combination system of Glycolipids (A) and Man Lau, the net concentration of the catalytically effective component, Glycolipid (A), was kept constant ( $2 \times$ $10^{-6} \mathrm{~mol}$ of the glycolipid catalyst per $1.25 \times 10^{-7} \mathrm{~mol}$ of a substrate) in $3 \mathrm{~mL}$ of tris buffer ( $\mathrm{pH}$ 7.8-8.0). The reaction was consistent with the mechanism presented by Michaelis ${ }^{-}$ Menten. Thus, the second-order rate constants $\left(k_{2}\right)$ and Michaelis constants $\left(K_{m}\right)$ were obtained by conventional methods.

\section{Results and Discussion}

\subsection{Recongnition of the kinds of amino acids}

It has been already reported that a glycolipid, synthesized by the authors, in hydrolyses of amides of amino acids, distinguishes the hydrophobic nature of side chains of amino acids, just as $\alpha$-chymotrypsin does ${ }^{3)}$. Figure 1 shows the results of substrate recognition obtained using Man( $\mathrm{Lau})_{2}-\mathrm{HisCOOMe}$, and includes, for comparison, a part of the results reported so far. The $\operatorname{Man}(\mathrm{Lau})_{2}$ showed the relative ability of substrate recognition of 0.35 (the value was calculated from the slope of linear part, taking the value of $\alpha$-chymotrypsin as one). A micelle-forming glycolipid, Man Lau, could also recognize the kinds of amino acids and its ability was estimated as 0.20 . Glycolipid (A), on the other hand, showed a very low ability of 0.14 .

It was found, however, that the combination system of Glycolipid (A) and Man Lau did not behave like $\alpha$-chymotrypsin in terms of the substrate recognition, although the individual component shows a similarity to $\alpha$-chymotrypsin. Thus, the recognition ability for amino acids could not be calculated for such combination systems, because of the lack of linear relation of second-order rate constants to hydrophobic nature of amino acids. In addition, the curvature of the non-linear part depended on the mixing ratio of Glycolipid (A) and Man Lau. These results well suggest that both components are not in the same conformation, regardless of the mixing ratios, in the combination system, but one of them exists as islands (colonies) in the sea of the other, that is, they take different shapes depending on the mixing ratios. In such circumstances, hydrolysis is supposed to occur or proceed near the interface of the components, Glycolipid (A) and Man Lau, rather than in the inside of each component.

\subsection{Recognition of the $\mathrm{D}, \mathrm{L}$-configuration of amino acids}

Synthesized glycolipids hydrolyze amide bonds ${ }^{6}$, which are not cleaved by the models proposed by others. In addition, they showed the D,L-recognition ability for amino acids, though it was remarkably low. The result is summarized in Table 1, which shows the ratios of second-order rate constants for hydrolyses of $\mathrm{D}$ and $\mathrm{L}$-amino acids $\left(k_{2 \mathrm{D}} / k_{2 \mathrm{~L}}\right)$. As substrates, phenylalanine anilide and alanine anilide were chosen. The former is a representative amino acid having a side chain with a high hydrophobic nature, and the latter, having one with a low hydrophobic nature. As seen from Table 1, there is no remarkable correlation between the ratio and the configuration of sugar moieties of glycolipids, which is surprising, since the configuration of hydroxyls on 2,3-positions of a sugar moiety has been found to be responsible for the recognition of $\alpha$ and $\beta^{-1,4-}$ glycoside bonds ${ }^{7}$ as well as to play 


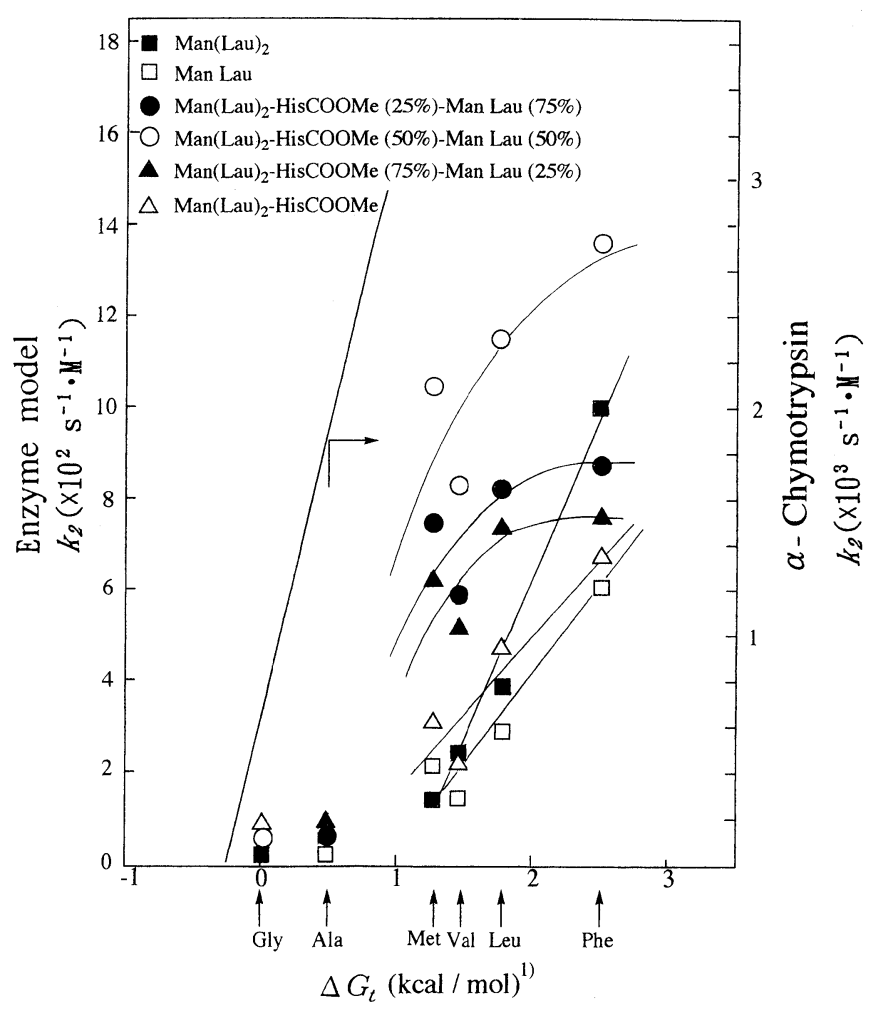

Fig. 1 Relationship between Second Order Rate Constants and Hydrophobicity Parameters.

Table 1 Ratios of Second-order Rate Constants $\left(k_{2} \mathrm{D} / k_{2} \mathrm{~L}\right)$ for Hydrolyses of $\mathrm{D}$ and $\mathrm{L}$-amino acids.

\begin{tabular}{|c|c|c|c|c|c|c|}
\hline & & 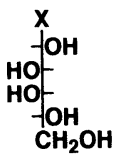 & 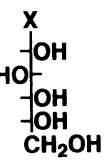 & $\begin{array}{c}\mathrm{X} \\
\mathrm{HO}- \\
\text { HO- } \\
\text { - } \mathrm{OH}_{\mathrm{OH}} \\
\mathrm{CH}_{2} \mathrm{OH}\end{array}$ & $\underset{\mathrm{CH}_{3}}{\stackrel{\mathrm{X}}{\mathrm{fOH}}}$ & \\
\hline & igar & Gal & Glc & Man & L-Rha & L-Fuc \\
\hline direct & Ala & 0.84 & 0.76 & 1.09 & & \\
\hline direct & Phe & 1.18 & 1.02 & 1.10 & & \\
\hline & Ala & 2.92 & 4.29 & 2.27 & 0.93 & 1.46 \\
\hline mintred & Phe & 1.10 & 2.18 & 1.12 & 1.05 & 1.00 \\
\hline & & - & $\begin{array}{l}\mathbf{x} \\
\text { - } \mathrm{OH} \\
-\mathrm{OH} \\
-\mathrm{OH} \\
\mathrm{CH} \\
\mathrm{H}_{2} \mathrm{OH}\end{array}$ & $\begin{array}{c}\mathrm{X} \\
\mathrm{HO} \\
\mathrm{fOH}_{\mathrm{OH}} \\
\mathrm{CH}_{2} \mathrm{OH}\end{array}$ & $\begin{array}{r}\text { direct } \\
X=\end{array}$ & \\
\hline & Igar & Xyl & Rib & Ara & indirect & \\
\hline direct & Ala & 0.98 & 1.19 & 0.63 & & \\
\hline direct & $\begin{array}{l}\text { |Phe } \\
\text { /Ala }\end{array}$ & $\begin{array}{l}1.20 \\
1.12\end{array}$ & $\begin{array}{l}1.07 \\
1.07\end{array}$ & $\begin{array}{l}1.33 \\
1.26\end{array}$ & & \\
\hline indirect & $\left\{\begin{array}{l}\text { Phe } \\
\text { Phe }\end{array}\right.$ & 1.43 & 1.39 & 1.01 & & \\
\hline
\end{tabular}

an important role in the recognition of the kinds of amino acids ${ }^{3), 8)}$. Considering that almost all the ratios are in the range from 0.6 to 1.5 , which might be within the range of experimental errors, further discussion may have to be avoided about the recognition of $\mathrm{D}, \mathrm{L}$-configuration by glycolipids themselves.

It was found, however, that the introduction of amino acid residue into a glycolipid en- 


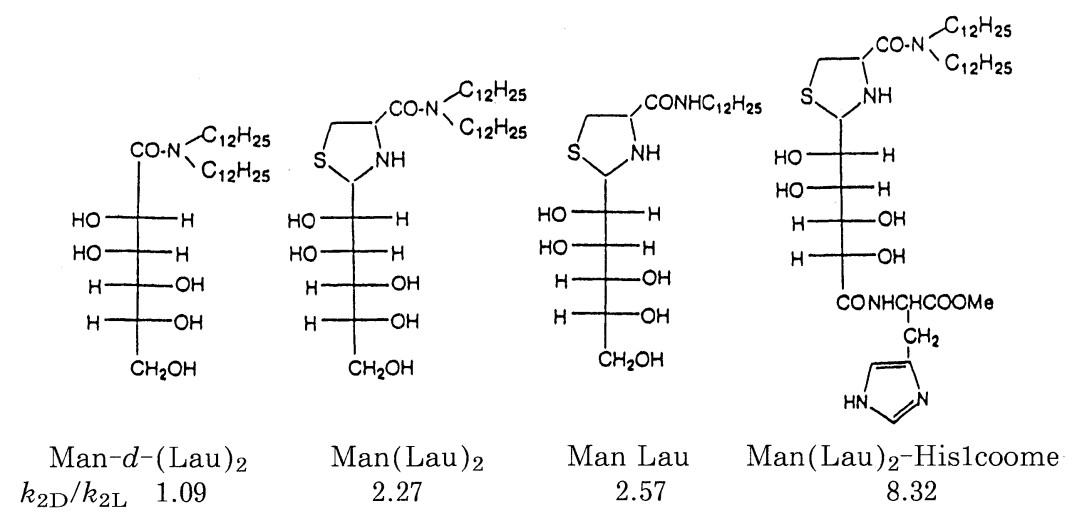

hanced D,L-recognition as follows :

The development of the $\mathrm{D}, \mathrm{L}-$ recognition ability of a glycolipid may need the presence of amino acid residue in a glycolipid. In the past, the authors reported a remarkably high $\mathrm{D}, \mathrm{L}^{-}$ recognition in the hydrolyses of phenylalanine $p$-nitro-phenyl esters. The glycolipids of

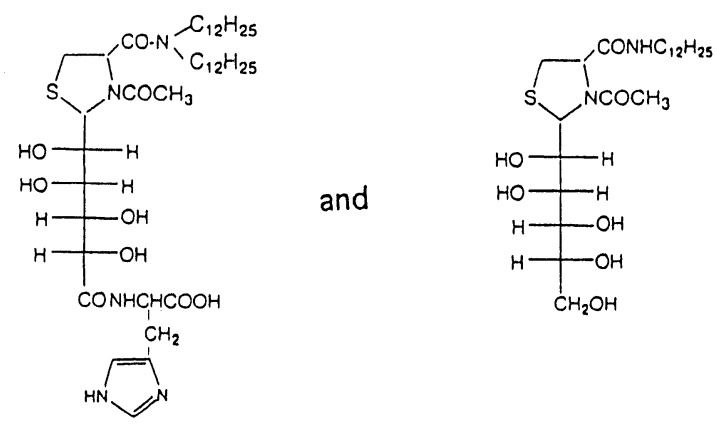

gave the recognition values of 61.05 and 0.88 , respectively, but their mixed vesicular model system (mole ratio of 1 to 1 ) showed the D,L-recognition value of $96.20^{4}$ ). Thus, the similar systems were also examined in the hydrolyses of $\mathrm{D}, \mathrm{L}$-amino acid amides.

Shown in Fig. 2 is the dependence of second-order rate constants on the composition of mixed vesicular systems in the hydrolyses of alanine anilides. As mentioned in the Experimental section, each system contains the same amount of Glycolipid (A). Nevertheless, a dramatic change in the rate constants was observed, depending on D and L anilides. L-Alanine anilide, for example, was hydrolyzed with a significantly increased rate by adding only $10 \mathrm{~mol} \%$ of Glycolipid (A), but further addition did not remarkably change the rate constants. While $\mathrm{D}^{-}$alanine anilide, on the other hand, was hydrolyzed at a little higher rate by addition of a small amount of Glycolipid (A), the addition of Glycolipid (A) in the range of 20 to $30 \mathrm{~mol} \%$ did not hydrolyze the anilide at all. Futher added Glycolipid (A) served to recover some hydrolysis activity, in spite of a lower rate. These results show that a combination system, which contains 20 to 30 mol\% of Glycolipid (A), can distinguish the D and L configurations of alanines perfectly, like enzymes.

The effect of the combination ratio of Glycolipid (A) and Man Lau on the recognition of $\mathrm{D}, \mathrm{L}-$ configuration of four amino acids is shown in Fig. 3. The hydrophobicity of amino acids is in the order of $\mathrm{Phe}>\mathrm{Val} \geqq \mathrm{Met}>$ Ala. The recognition for each amino acid, on the other hand, was in the order of $\mathrm{Ala}>\mathrm{Val}>\mathrm{Met} \geqq \mathrm{Phe}$. Except for methionine which has a polar group in the side chain, the less the hydrophobicity, the higher the D,L-recognition activity. It is found by studying Fig. 3 in more detail that there are possibly two combination ratios 


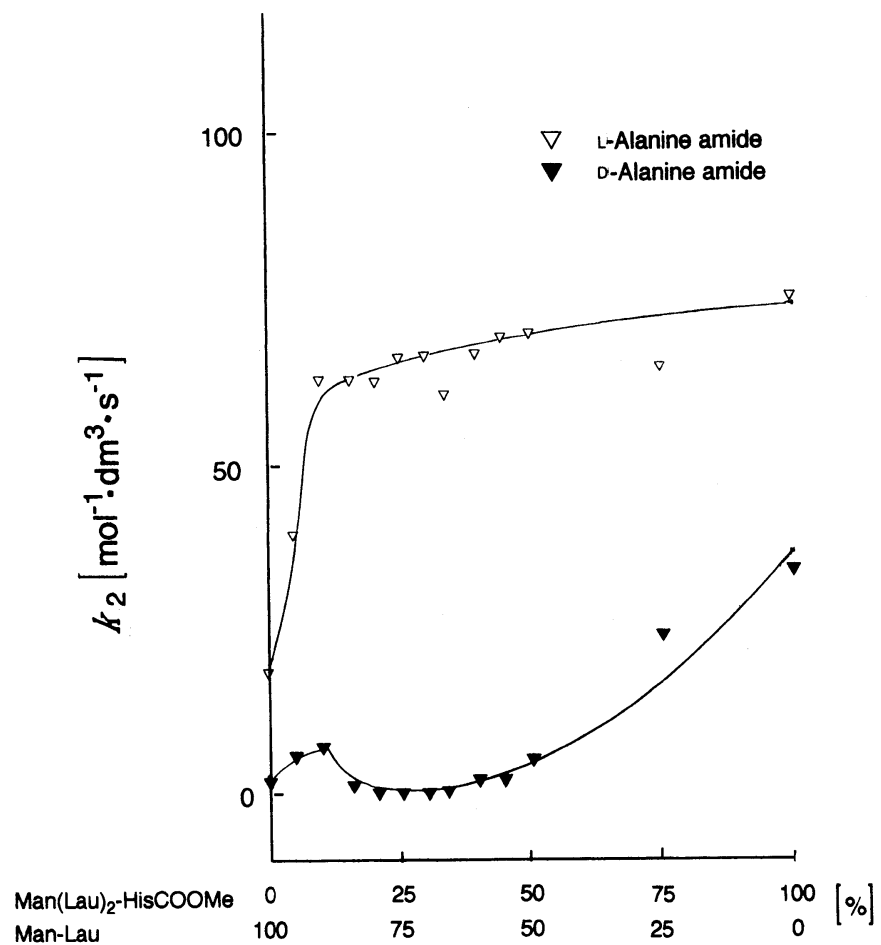

Fig. 2 Recognition of D,L-Alanines Using Catalyst System Consisting of Man(Lau $)_{2}-\mathrm{HisCOOMe}$ and ManLau.

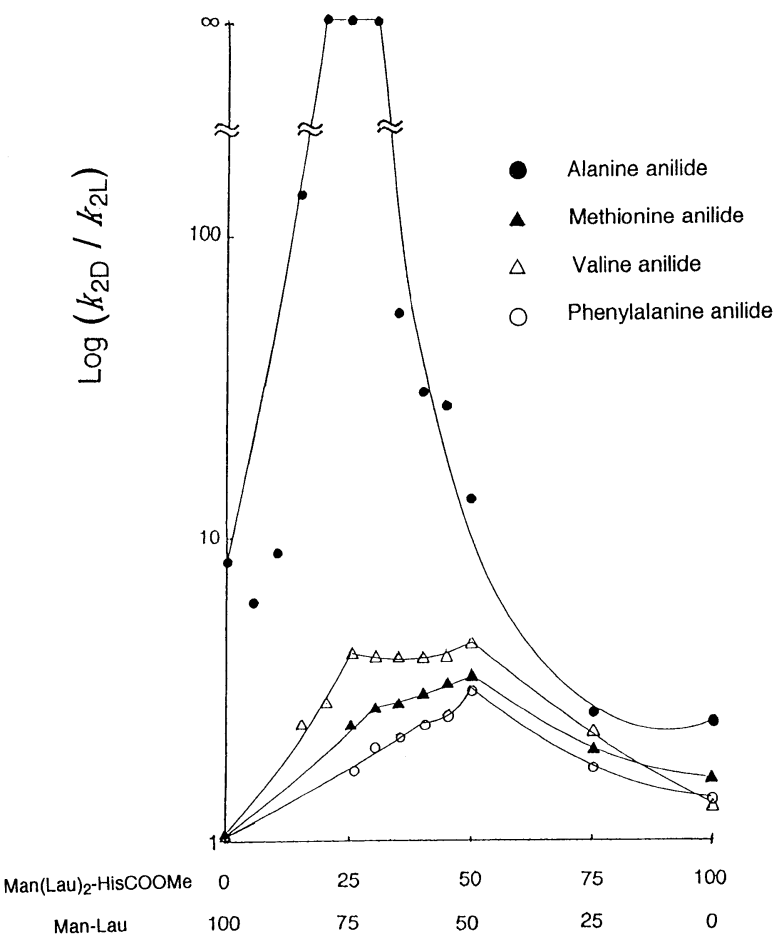

Fig. 3 Stereoselective Hydrolyses Using Catalyst System Consisting of Man(Lau $)_{2}-$ HisCOOMe and Man-Lau. 
Table 2 Kinetic Parameters of Catalyst Systems Containing 10 or 15 mol\% of $\mathrm{Man}(\mathrm{Lau})_{2}-\mathrm{HisCOOMe.}$

\begin{tabular}{ccccccc}
\hline & \multicolumn{3}{c}{$10 \%$} & & \multicolumn{2}{c}{$15 \%$} \\
\cline { 2 - 3 } \cline { 5 - 6 } & $\mathrm{L}^{-}$ & $\mathrm{D}^{-}$ & & $\mathrm{L}^{-}$ & $\mathrm{D}^{-}$ \\
\hline$K_{\mathrm{m}}[\mathrm{M}]$ & $5.0 \times 10^{-5}$ & $25.0 \times 10^{-5}$ & & $7.7 \times 10^{-5}$ & $33.3 \times 10^{-5}$ \\
$k_{\mathrm{cat}}\left[\mathrm{s}^{-1}\right]$ & $27.2 \times 10^{-3}$ & $49.9 \times 10^{-3}$ & & $20.7 \times 10^{-3}$ & $5.0 \times 10^{-3}$ \\
$k_{2}\left[\mathrm{~mol}^{-1} \cdot \mathrm{dm}^{3} \cdot \mathrm{s}^{-1}\right]$ & 63.8 & & 7.4 & & 62.3 & 0.5 \\
$k_{2} \mathrm{~L} / k_{2} \mathrm{D}$ & & 8.7 & & & 135.5 & \\
\hline
\end{tabular}

which give higher recognition of $\mathrm{D}, \mathrm{L}^{-}$-configurations : that is, the presence of Glycolipid (A) at the concentration of 25 or $50 \mathrm{~mol} \%$ seems to give a higher $\mathrm{D}, \mathrm{L}-$-recognition. The former concentration, in particular, seems effective for the recognition of less hydrophobic $\mathrm{D}, \mathrm{L}^{-}$ amino acids, while the latter seems effective for the recognition of more hydrophobic D, $\mathrm{L}^{-}$ amino acids.

These phenomena also suggest that the shape and size of aggregates of Glycolipid (A) dispersed in Man Lau, probably heterogeneously as mentioned above, are important in developing the ability for D, L-recognition. In other words, Glycolipid (A) is considered to function in the form of molecular aggregates rather than individual molecules.

The step was examined, in which the stereochemistry of a $\mathrm{D}, \mathrm{L}^{-}$amino acid, especially $\mathrm{D}, \mathrm{L}^{-}$ alanine, was recognized. Table 2 shows the kinetic parameters of the enzyme model systems containing 10 or 15 mol\% of Glycolipid (A). These concentrations were chosen on the basis of the concentrations which showed greater increased abilities of hydrolysis and recognition of $\mathrm{D}, \mathrm{L}$-alanines, because the kinetic parameters at 20 to 30 mol\% of Glycolipid (A) could not be determined due to the lack of data on the observed hydrolysis of $\mathrm{D}^{-}$alanine amide.

As seen in Table 2, $k_{2 \mathrm{~L}} / k_{2 \mathrm{D}}$ increases dramatically from 8.7 to 135.5 , although the rate constants are approximately the same for L-alanine anilide and decrease from 7.4 to 0.5 for $\mathrm{D}^{-}$ alanine anilide, when Glycolipid (A) is allowed to increase from 10 to 15 mol\%. According to the $K_{\mathrm{m}}$ values, $\mathrm{L}$-alanine anilide is taken up 4 to 5 times more easily than $\mathrm{D}$-alanine anilide, but both $\mathrm{D}^{-}$and $\mathrm{L}^{-}$-alanine anilide gives about the same values of $K_{\mathrm{m}}$ at 10 and 15 mol\% of Glycolipid (A). That is to say, the degree of uptake looks unaffected by the concentrations of Glycolipid (A). On the contrary, the $k_{\text {cat }}$ values for $\mathrm{D}^{-}$-alanine anilide are quite different, depending on the concentration of Glycolipid (A), although those for L-alanine anilide are not appreciably different. This fact shows that overall rate constant $k_{2}$ is mainly concerned with rate constatns $k_{\text {cat }}$ rather than $K_{\mathrm{m}}$ value. Thus, the recognition of D,L-configuration is considered to occur mainly in the step in which the complex in Michaelis-Menten mechanism is decomposed into hydrolysates and the original enzyme model (A), in addition to a little recognition in the taking-in process.

The step of $\mathrm{D}, \mathrm{L}-$-recognition clarified in this study cannot be explained satisfactorily by the "lock and key" theory, which says that an enzyme takes in only the substrate (key) having a chemical sturcture fitted in the hole (lock) of an enzyme. The molecular recognition performed in the decomposition step of the complex in Michaelis-Menten mechanism, as mentioned above does not seen peculiar only to an enzyme model system.

(Received Jul. 19, 1995 ; Accepted Mar. 13, 1996)

\section{References}

1) R. Ueoka, R.A. Moss, S. Swarup, Y. Matsumoto, G. Strauss, Y. Murakami, J. Am. Chem. Soc., 107, 2185 (1985).

2) R. Ueoka, Y. Matsumoto, T. Yoshino, N. Watanabe, K. Omura, Y. Murakami, Chem. Lett., 1986, 1743. 
3) Y. Ohkatsu, T. Sueyoshi, J. Jpn. Oil Chem. Soc., 43, 220 (1994).

4) K. Kawaguchi, K. Isobe, Y. Ohkatsu, T. Kusano, J. Jpn. Oil Chem. Soc., 41, 458 (1992).

5) Y. Ohkatsu, K. Hamada, M. Saitoh, J. Jpn. Oil Chem. Soc., 42, 359 (1993).

6) Y. Ohkatsu, N. Nakamura, J. Jpn. Oil Chem. Soc., 44, 179 (1995).

7) Y. Ohkatsu, T. Kuba, J. Jpn. Oil Chem. Soc., 44, 30 (1995).

8) Y. Ohkatsu, N. Nakamura, J. Jpn. Oil Chem. Soc., 45, 537 (1996). 
[報文]

糖脂筫酵菜モデル (第 9 報)

糖残基の立体配員の影響

大勝 靖一 - 中 村 亘 宏

工学院大学工学部応用化学科（F163 東京都新宿区西新宿1-24-2）

ヘキソース，ペントース，およびテトロース型の糖脂質を用いてアミノ酸アミドを加水分解した。糖脂質として は，親水性糖残基と疎水性残基の間に連結基としてチアゾリジン環を有するもの（間接型糖脂質）と有さないもの

（值接型糖脂質）を使用した。一般に前者の糖脂質は後者のものよりも活性が高く，基質識別能や加水分解活性の ような活性は糖残基の C -2 および C -3 位のヒドロキシル基の立体配置と関係のあることが判明した。すなわち， それらのヒドロキシル基がL-トレオ型の糖脂質は両活性共に高い活性を示し，一方D-トレオ型のそれは共に低い活 性を示した。またエリトロ型の糖脂質はそれらの中間的な活性を示した。

(連絡者 : 大勝靖一) Vo1. 45, No. 6, 537 (1996).

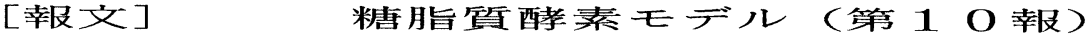 \\ アミノ酸残基を有する糖脂質の触媒活性}

大 勝靖一 - 小沢美保 - 沼田良子・中村亘宏 工学院大学工学部応用化学科（テ̄163 東京都新宿区西新宿1-24-2）

二つの範疇に入る糖脂質を合成し，加水分解酵素モデルとしてアミノ酸の $\mathrm{p}-$ ニロアニリドの加水分解に適用 した。一つの糖脂質は糖脂質分子の末端に糖残基を有し，そして他は糖残基の $\omega$-位にヒスチジン基を有した。両 方の種類の糖脂質は， $\alpha$-キモトリプシンと同様にアミノ酸の種類を識別する事ができたが, 両範疇の糖脂質の組 み合わせ系はそれと異なった具合にアミノ酸の種類を識別した。しかしながら，その組み合わせ系はアミノ酸のD, L-立体配置を他のモデルよりも良好に識別した。特に，それはD，L-アラニンを酵素のように完全に識別した。こ の識別機構が議論される。

（連絡者: 大勝靖一） Vol.45, No. 6, 545 (1996).

\section{[報文]ニンジン汁液に植えた醰母による脂質生座 及びその組成变化（第1 報)}

Marek Gogolewski, Piotr Makarewicz, and Malgorzata Nogala-Kalucka Department of Food Biochemistry and Analysis, Faculty of Food Technology, Agricultural University (60-623 Poznan, 48 Mazowiecka St., Poland.)

国内連絡先：日本食品油脂検査協会 丸山武紀 （i103 東京都中央区日本橋浜町3-27-8）

ニンジン汁液に植えた酵母 10 株中より, Phodotorula gracilis 2 及びTrichosporon cutaneum 1 を選択した。 Wickerham(W)の方法で調製した培養液による予備試験では, 上記 2 株の油脂生産性が優れていた。 $\beta$ ーカロテン生 産後の二ンジン汁液廃水を油脂生産酵母の培養に用いた。培養した酵母菌体より得られる油脂のアシルグリセリン 遊離脂肪酸, リン脂質, ステロール及び核酸を定量した。 